\title{
sciendo
}

DOI: $10.2478 /$ rjti-2019-0003

ROMANIAN JOURNAL

OF TRANSPORT INFRASTRUCTURE

\section{LOESSOID SOILS IMPROVEMENT - LABORATORY TESTS AND ROAD ENGINEERING APPLICATIONS}

Cong Dinh Nguyen, Ph.D. candidate, Technical University of Civil Engineering Bucharest, e-mail: congdinh2610@gmail.com

Catalin Burlacu, Ph.D., Teaching Assistant, Technical University of Civil Engineering Bucharest, e-mail: cataburlacu@gmail.com

Ioan Boti, Ph.D., Lecturer, Technical University of Civil Engineering Bucharest, e-mail: ioanboti@yahoo.com

\section{Rezumat}

Pământurile sensibile la umezire (PSU) sunt pământuri coezive macroporice nesaturate care, la contactul cu apa, suferă modificări bruște și ireversibile ale structurii interne, reflectate prin tasări suplimentare cu caracter de prăbușire. Din această categorie fac parte loessurile, pământurile loessoide și alte pământuri preponderent prăfoase, cu porozitate marcant neuniformă.

O metodă des utilizată în vederea îmbunătătirii pământurilor sensibile la umezire este cea a realizării de perne sau coloane din material local compactat. In acest articol sunt prezentate atât programele experimentale realizate în vederea obținerii unui amestec optim de materiale locale (loess) cu diferite alte materiale (nisip, bentonită, ciment) în scopul îmbunătățirii caracteristicilor mecanice cât și rezultatele mai multor calcule de tasare pentru două studii de caz.

Cuvinte cheie: pământuri sensibile la umezire, amestecuri de pământ, tasare, rambleu, cai de comunicatii

\section{Abstract}

Moisture-sensitive or collapsible soils are materials with high porosity that under the loads transmitted by the superstructure or even under its own weight present additional settlements once the soil is saturated. This category includes loess deposits and other high silt content soils with uneven porosity. A method often used for foundation on these soils is the realization of local loessoid material compacted columns. This paper presents, on one hand, the experimental laboratory programs aiming to achieve some optimal mixtures of local material (loess) and different other materials (sand, bentonite, cement) in order to improve the values of the mechanical parameters of the soil and so, to limit the settlements. On the other hand, it presents a lot of settlement calculations for different case scenarios.

Keywords: collapsible soils, soil mixtures, settlement, embankment, roads 
ROMANIAN JOURNAL

OF TRANSPORT INFRASTRUCTURE

Cong Dinh Nguyen, Catalin Burlacu, Ioan Boti

Loessoid soils improvement - laboratory tests and road engineering applications

\section{INTRODUCTION}

Moisture-sensitive or collapsible soils are unsaturated macroporous cohesive soils that, upon saturation with water, undergo sudden and irreversible changes of the internal structure, reflected by additional settlements with collapsing character and lower values for mechanical parameters (decreases in the values of geotechnical parameters of mechanical behavior (NP 125: 2010)).

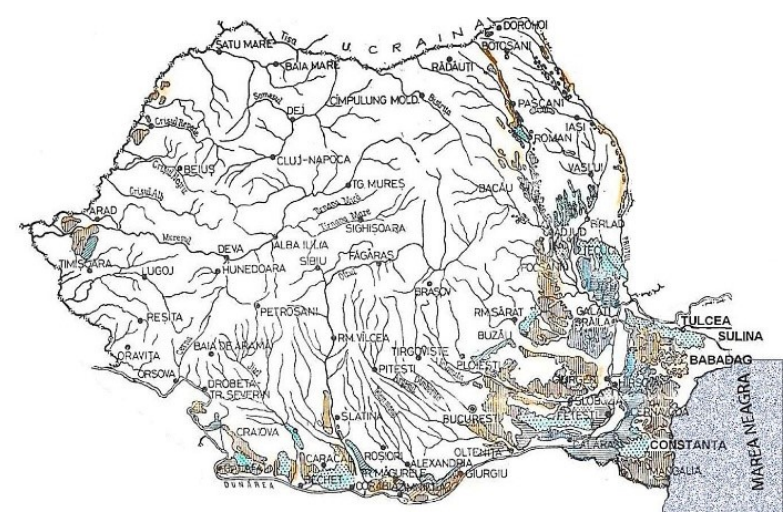

Figure 1. Collapsible soil spreading in Romania (NP 125:2010).

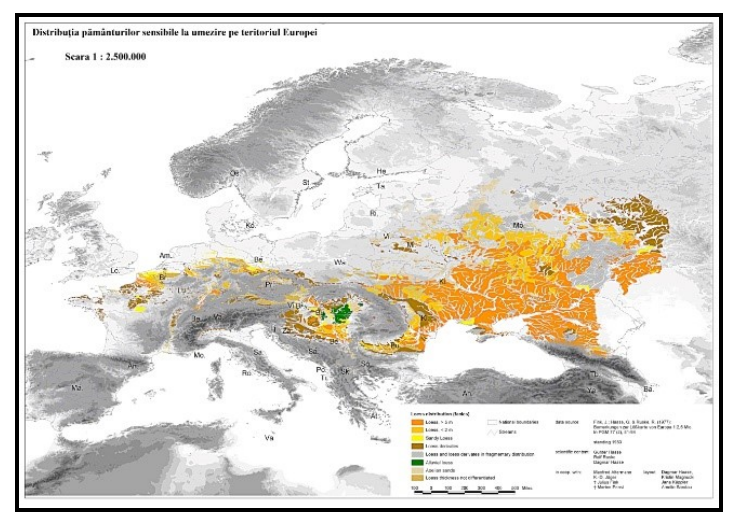

Figure 2. Collapsible soil spreading in Europe (D. Haase et al., 2007).

It covers about 7\% of Europe's territory (especially in Russia, Romania, Bulgaria, Hungary, Poland, Austria and less in the west of the continent (Figure 2). In Romania, moisture-sensitive soils cover about $19 \%$ of the country's territory (approximately $40.000 \mathrm{~km}^{2}$ ) and it is common particularly in the eastern part of the country (Figure 1).

In order to characterize a soil as moisture sensitive, at least one criterion regarding the physical characteristics and one criterion regarding the mechanical behavior must be met, the main criteria being the following:

A. Criteria regarding physical characteristics:

- percentage of silt fraction: $50-80 \%$

- degree of saturation: $\mathrm{S}_{\mathrm{r}}<0,8$

- porosity in natural state: $n>45 \%$

B. Criteria regarding mechanical behavior:

- the index of the additional settlement caused by saturation under a loading of $300 \mathrm{kPa}$ (in oedometric test): $\mathrm{i}_{\mathrm{m} 300} \geq 2 \%$. 
ROMANIAN JOURNAL

OF TRANSPORT INFRASTRUCTURE

Cong Dinh Nguyen, Catalin Burlacu, Ioan Boti

Loessoid soils improvement - laboratory tests and road engineering applications

\section{IMPROVEMENT METHODS FOR COLLAPSIBLE SOILS}

The methods of improving difficult foundation soils keep developing, not only quantitatively, but also qualitatively, as a result of both the progress of new technologies and the recognition of economic and environmental protection benefits of modern methods.

A significant number of techniques aimed at improving the mechanical characteristics of difficult foundation soils have been developed. Methods are divided into two major categories (Schlosser 1997):

- $\quad$ physical methods - soil improvement technologies, by which soil structure is mainly improved in what concerns contacts between particles using additives or by reducing porosity in order to increase the tamping state physical characteristics improvement methods;

- mechanical methods - mainly soil reinforcing technologies where more rigid elements are introduced into the ground in order to prevent large settlements or even failure of the foundation soil.

Classification of results sought by difficult foundation soil improvement (Kirsch, Sondermann 2003):

- $\quad$ increasing density and shearing strength

- $\quad$ reducing compressibility

- influencing permeability in order to reduce infiltrated water flow or to speed up consolidation process

- improving homogeneity.

\section{LABORATORY TESTS}

In the experimental programs, various mixtures of loessoid material with different natural mineral materials have been proposed, in view of eliminating moisture sensitiveness, improving geotechnical parameters of mechanical behavior and limiting permeability values.

For this purpose, conducting 2 experimental programs, a series of mixtures have been proposed:

\section{Program 1:}

Mixture 1: $80 \%$ loess $+20 \%$ sand $(1-2 \mathrm{~mm})$;

Mixture 2: $60 \%$ loess $+40 \%$ sand $(1-2 \mathrm{~mm})$;

Mixture 3: $50 \%$ loess $+40 \%$ sand $(1-2 \mathrm{~mm})+10 \%$ bentonite - all the three materials were simultaneously mixed and then water was added; 
ROMANIAN JOURNAL

Mixture 4: $50 \%$ loess + mixture from $(40 \%$ sand $(1-2 \mathrm{~mm})+10 \%$ bentonite) - the sand was first mixed with the bentonite and with water and then, after this mixture had dried, it was also mixed with the loess;

\section{Program 2:}

- Method 1 (M1): Loess mixed with water, stored for 1 day, then mixed with cement $(2 \%, 4 \%, 6 \%)$ and compacted immediately;

- Method 2 (M2): Loess mixed with cement (4\%), then mixed with water, stored for 1 day and then compacted;

- Method 3 (M3): Loess mixed with cement (6\%), then mixed with water and then compacted immediately.

For the first experimental program, the Proctor test results showed that, along with adding up and increasing the percentage of sand in the mixture (from $20 \%$ to $40 \%$ ), the maximum density in dry condition increases and, at the same time, the optimal compaction moisture content of the mixtures decreases.

In case of mixture 4, the same tamping state was obtained for moisture values between $11 \%$ and $15 \%$. Given that moisture content plays a key role in the real scale compaction process, this indication is important because it allows compaction at moisture values belonging to wider moisture content domains.

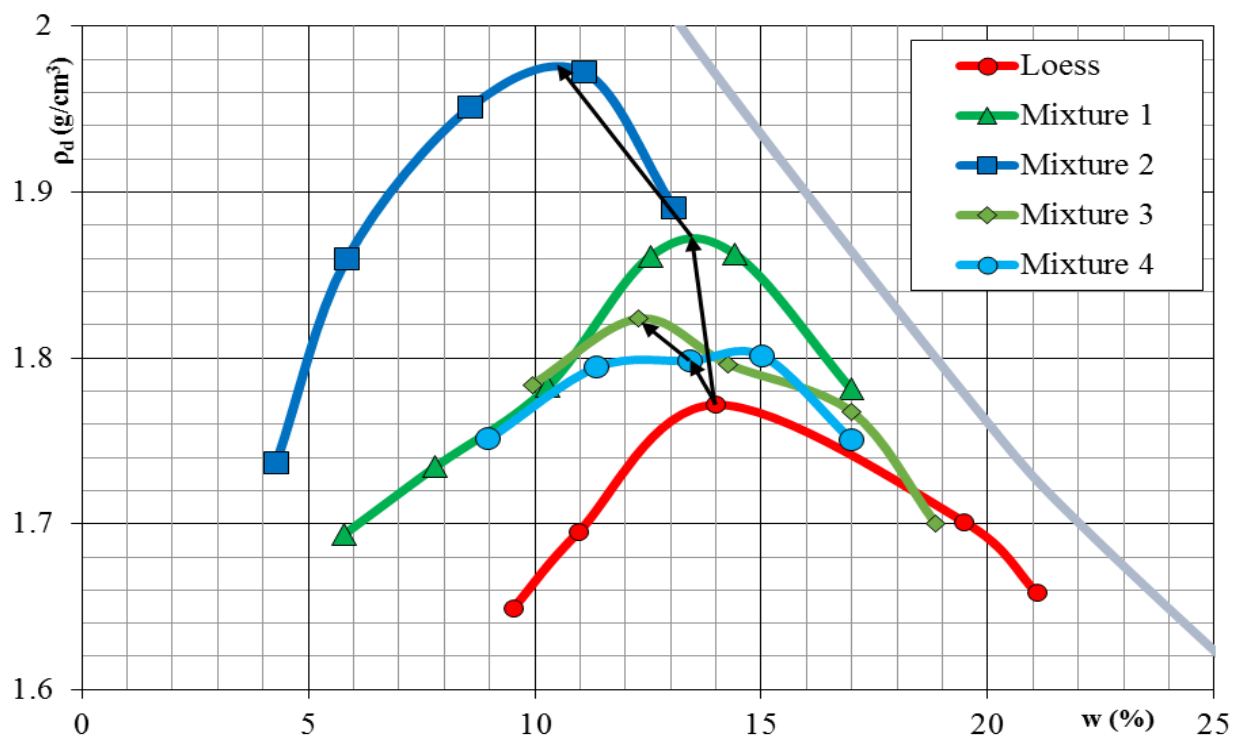

Figure 3. Results of the Proctor tests for all the mixtures of the first experimental program.

The synthesis of the oedometer compressibility tests, based on the oedometric moduli values, indicated that the same values $\mathrm{E}_{\text {oed 200-300 }}$ could be 
ROMANIAN JOURNAL

OF TRANSPORT INFRASTRUCTURE

Cong Dinh Nguyen, Catalin Burlacu, Ioan Boti

Loessoid soils improvement - laboratory tests and road engineering applications

obtained for the mixture containing an addition of sand of $20 \%$, at smaller moisture values and at a better tamping state than in case of the natural loess samples. This trend disappeared once the percentage of sand in the mixture was increased. In what concerns samples with bentonite, similar values of oedometric moduli were obtained at a better tamping state that in case of medium loess samples, but at a reduced tamping state than in case of samples with sand, which was also confirmed by the values obtained following Proctor tests.

Table 1 - The synthesis of the results for the oedometer compressibility tests

\begin{tabular}{|c|c|c|c|c|c|}
\hline & $\begin{array}{c}\mathrm{E}_{\mathrm{oed}} 200-300 \\
(\mathbf{k P a})\end{array}$ & $\begin{array}{c}10000- \\
11000\end{array}$ & $\begin{array}{c}12000- \\
15000\end{array}$ & $\begin{array}{c}20000- \\
21000\end{array}$ & $\begin{array}{l}23000- \\
25000\end{array}$ \\
\hline \multirow[t]{2}{*}{ Loess } & $w(\%)$ & $19.7-20.1$ & - & 12.1 & $14.1-17.00$ \\
\hline & $\rho_{d}\left(g / \mathrm{cm}^{3}\right)$ & $1.66-1.67$ & - & 1.68 & $1.69-1.77$ \\
\hline \multirow{2}{*}{$\begin{array}{c}\text { Mixture } \\
1\end{array}$} & w (\%) & 9.6 & 12.8 & - & 12.4 \\
\hline & $\rho_{\mathrm{d}}\left(\mathrm{g} / \mathrm{cm}^{3}\right)$ & 1.91 & 1.90 & - & 1.86 \\
\hline \multirow{2}{*}{$\begin{array}{c}\text { Mixture } \\
2 \\
\end{array}$} & $w(\%)$ & - & $12.7-12.9$ & 10.7 & - \\
\hline & $\rho_{\mathrm{d}}\left(\mathrm{g} / \mathrm{cm}^{3}\right)$ & - & $1.86-1.90$ & 1.98 & - \\
\hline \multirow{2}{*}{$\begin{array}{c}\text { Mixture } \\
\mathbf{3}\end{array}$} & $w(\%)$ & - & 12.3 & 12.4 & - \\
\hline & $\rho_{d}\left(\mathrm{~g} / \mathrm{cm}^{3}\right)$ & - & 1.84 & 1.79 & - \\
\hline
\end{tabular}

For the second laboratory program, after analyzing the Proctor results, it was observed that the second method isn't that effective (figure 4).
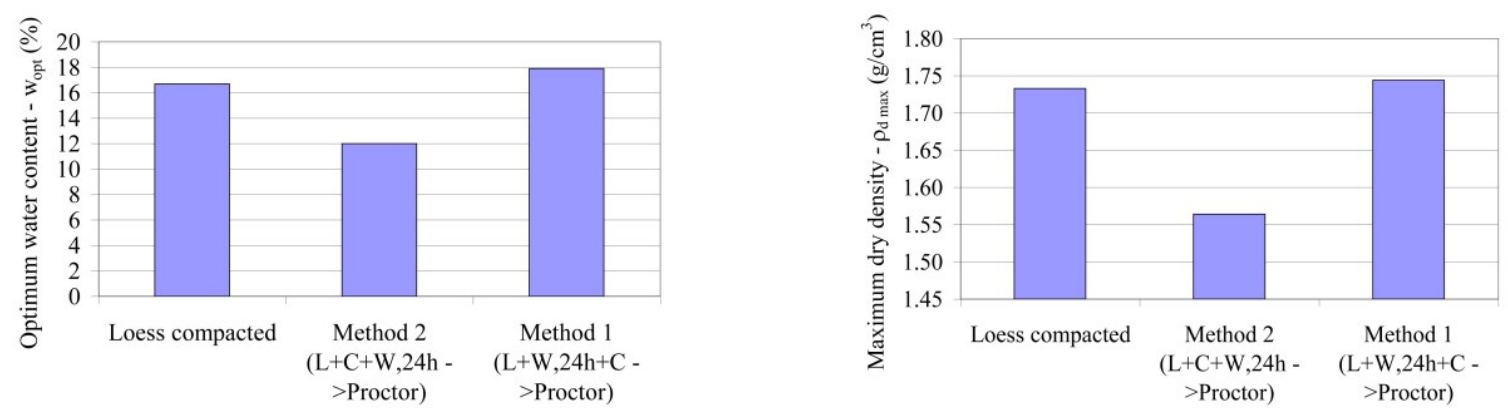

Figure 4. Effect of mixing methods 1 and 2 with $4 \%$ cement on optimum water content and maximum dry density.

The analysis of Proctor test results for mixture 1 and 3 showed that, along with adding up and increasing the percentage of cement in the mixture (from $2 \%$ 
ROMANIAN JOURNAL

OF TRANSPORT INFRASTRUCTURE

Cong Dinh Nguyen, Catalin Burlacu, Ioan Boti

Loessoid soils improvement - laboratory tests and road engineering applications

to $6 \%$ ), the maximum density in dry condition increases with a decrease of the optimal compaction moisture content (Figure 5).

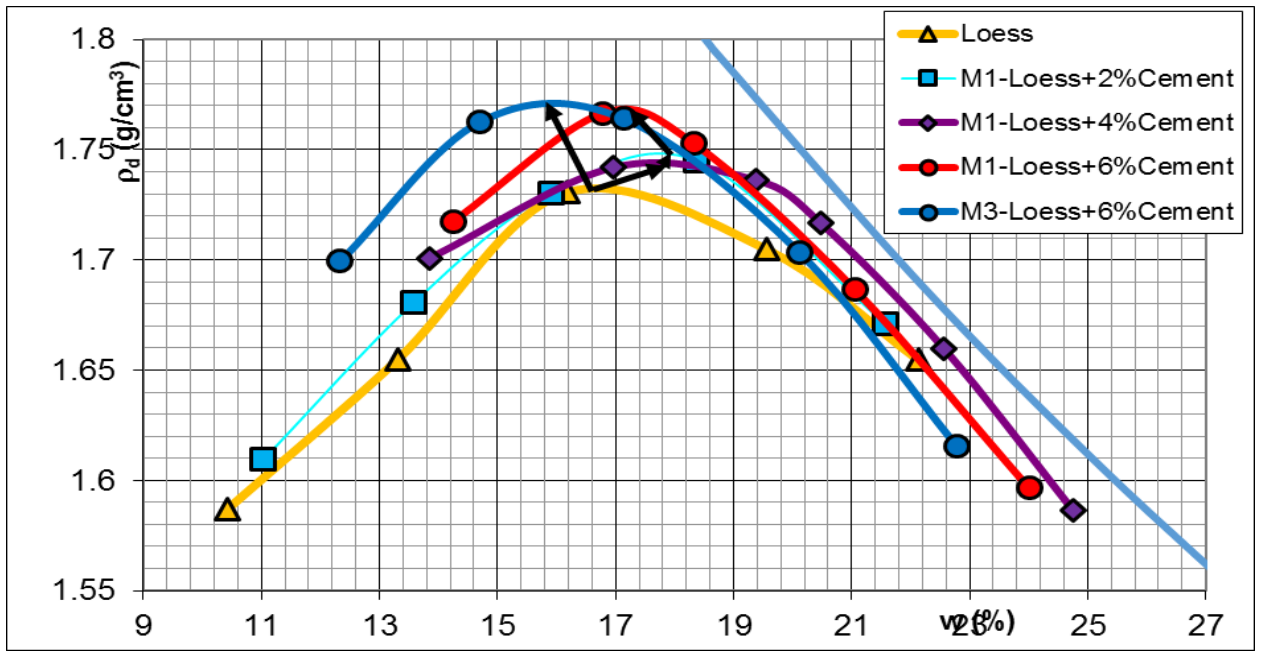

Figure 5. Results of the Proctor tests for the second experimental program.

Also, it was observed that, for the same percentage of cement in the mixture $(6 \%)$ a similar value for the maximum dry density is obtained, but at a smaller value of moisture content.
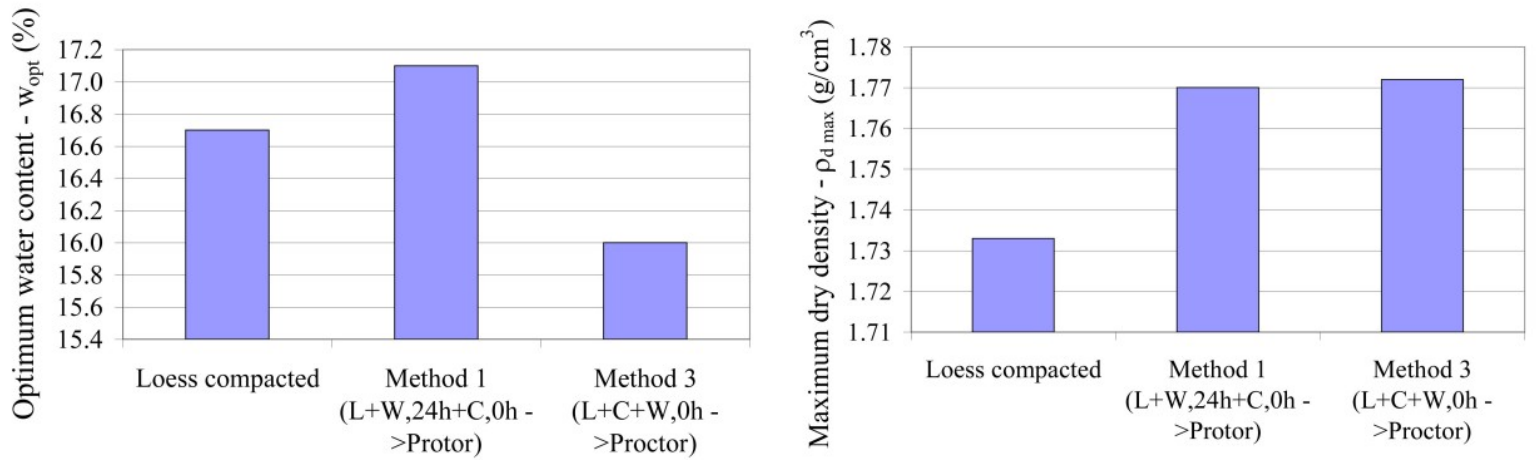

Figure 6. Effect of mixing methods 1 and 3 with $6 \%$ cement on optimum water content and maximum dry density.

In what concerns the oedometer compressibility tests, the results, for both mixing methods, were similar, as shown in the figure below. 
ROMANIAN JOURNAL

OF TRANSPORT INFRASTRUCTURE

Cong Dinh Nguyen, Catalin Burlacu, Ioan Boti

Loessoid soils improvement - laboratory tests and road engineering applications

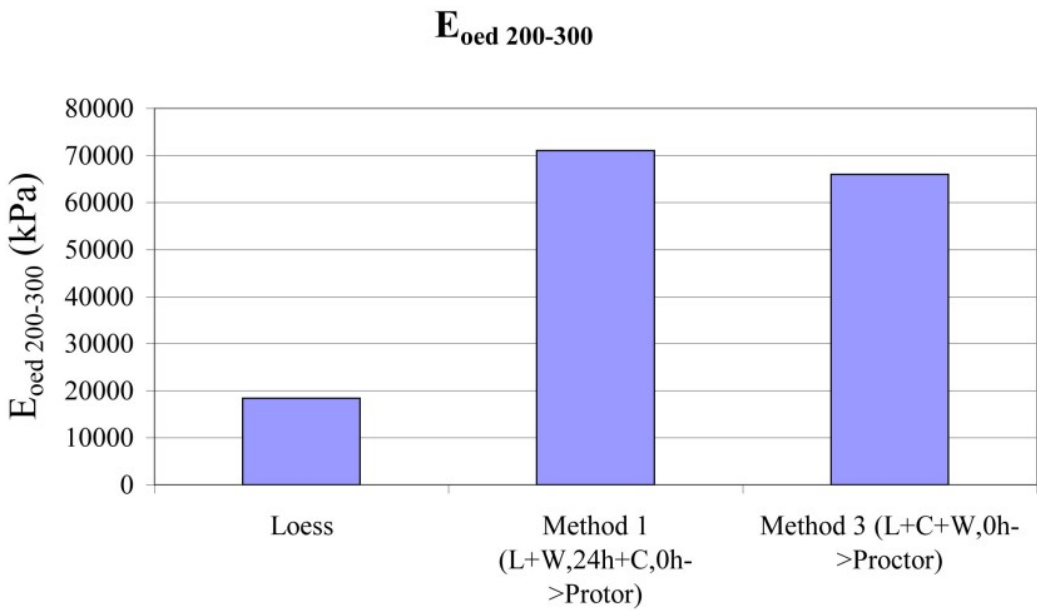

Figure 7. Comparison between compressibility tests results for mixture methods 1 and 3.

Also, unconfined compressive strength tests were conducted for these two mixing methods.

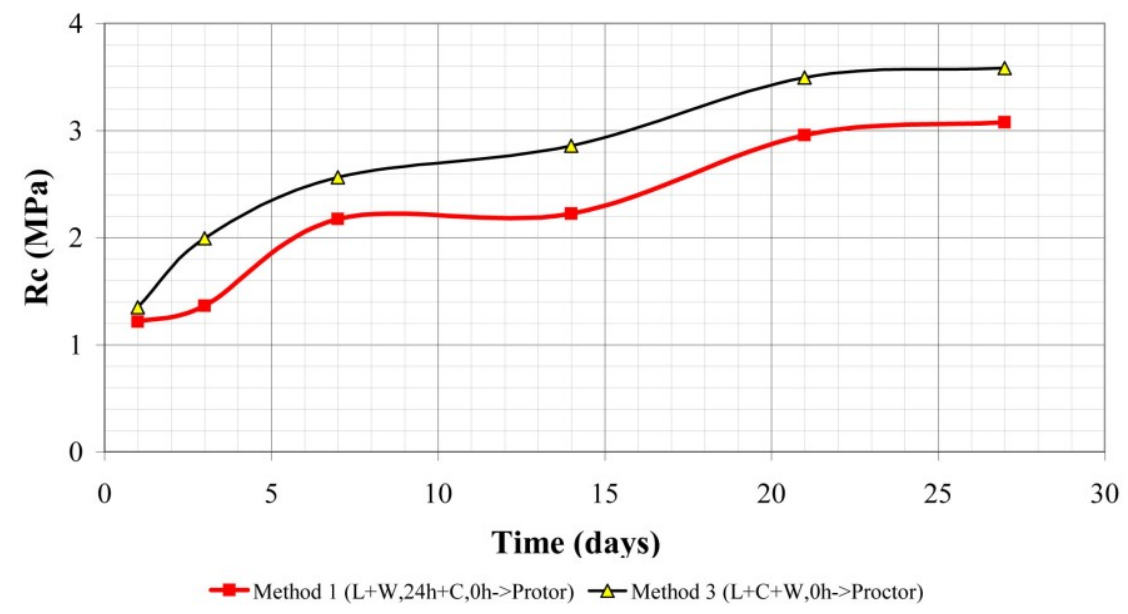

Figure 8. Comparison between unconfined compressive strength test results for mixture methods 1 and 3 .

\section{SETTLEMENT CALCULATION FOR COLLAPSIBLE SOILS}

\subsection{Settlement calculation methodology for collapsible soils}

The settlement calculation method for a collapsible soil is regulated by the national norm NP 125:2010. 
The additional settlement due to wetting under the overburden pressure $\left(\mathrm{I}_{\mathrm{mg}}\right)$ is calculated for the entire thickness of the moisture sensitive layer $\left(\mathrm{i}_{\mathrm{m} 300} \geq\right.$ $2 \%$ ) with the relation:

$$
I_{m g}=\sum_{1}^{N} i_{m g} \cdot h_{i}
$$

where: $\mathrm{N}$ - number of elementary layers;

$h_{i} \quad$ - the thickness of the elementary layers;

$i_{\text {mg }}$ - the index of supplementary settlement due to wetting of the elementary layer under its own weight.

$i_{m g}=\varepsilon_{g i}-\varepsilon_{g n}$

where: $\varepsilon_{\mathrm{gi}}$ - the specific deformation for the wetted soil $\sigma_{\mathrm{gi}}$ (calculated with the saturated unit weight);

$\varepsilon_{\mathrm{gn}}$ - the specific deformation for the natural soil $\sigma_{\mathrm{gn}}$ (calculated with the bulk unit weight in the middle of the elementary layer).

The supplementary settlement due to wetting under the loads transmitted by foundation $\left(\mathrm{I}_{\mathrm{mp}}\right)$ is calculated from the depth of the foundation $\left(\mathrm{D}_{\mathrm{f}}\right)$ for all deformable areas with the following relation:

$I_{m p}=\sum_{1\left(D_{f}\right.}^{N^{\prime}} i_{m p} \cdot h_{i}$

where: $\mathrm{N}^{\prime}$ - the number of elementary layers in the deformable areas;

$\mathrm{h}_{\mathrm{i}}$ - the thickness of the elementary layers;

$D_{\mathrm{f}}$ - the depth of foundation;

$i_{m p}$ - the index of supplementary settlement due to wetting of the elementary layer under the load transmitted by the foundation.

$i_{m p}=\varepsilon_{p i}-\varepsilon_{p n}$

where: $\varepsilon_{\mathrm{pi}}$ - the specific deformation for the wetted soil, for $p_{i}=\sigma_{g i}-\sigma_{z}$

$\varepsilon_{\mathrm{gi}}$ - the specific deformation for the wetted soil, for $\sigma_{\mathrm{gi}}$;

$\sigma_{z}$ - the vertical stress from the foundation load in the middle of the layer.

The supplementary settlement due to wetting is estimated for the deformable zones in the soil.

$s=I_{m g}+I_{m p}$ 
ROMANIAN JOURNAL

OF TRANSPORT INFRASTRUCTURE

Cong Dinh Nguyen, Catalin Burlacu, Ioan Boti

Loessoid soils improvement - laboratory tests and road engineering applications
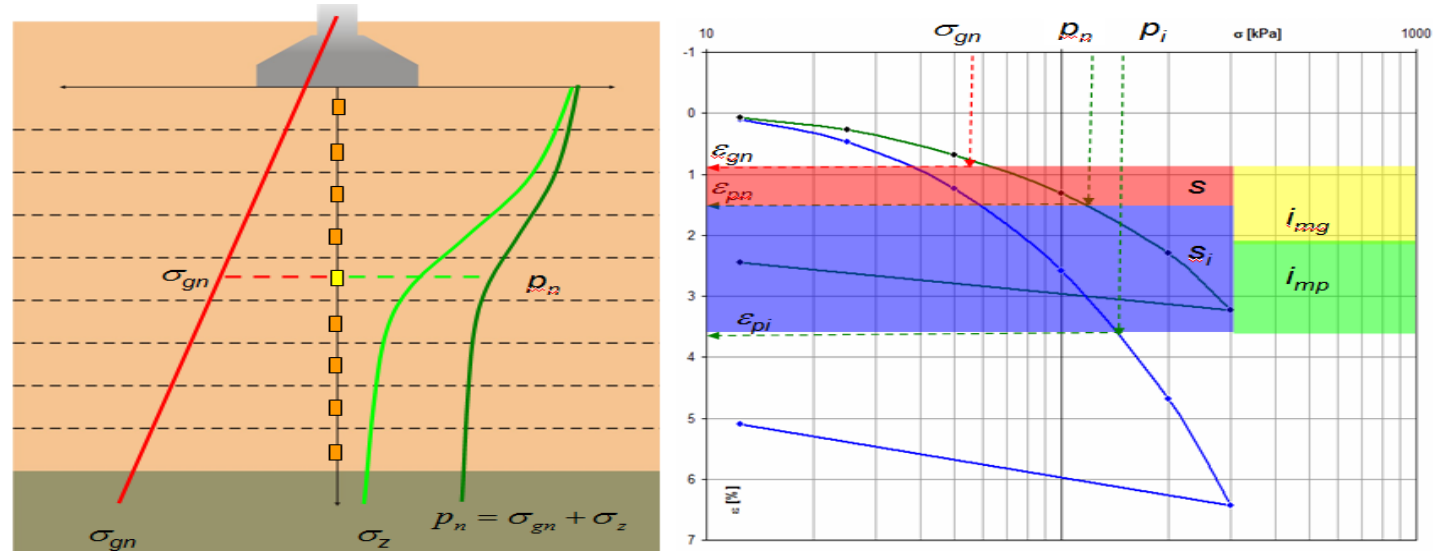

Figure 9. Settlement calculation for a collapsible soil [3]

\subsection{Case study}

Using the results from the experimental programs, a set of calculations were conducted, in order to observe the influence of studied mixtures (if used as filling materials in cushions and/or columns) in the settlement calculation for a road embankment.

Two situations were taken into consideration:

- Case 1 - 3m height embankment;

- Case 2 - 8m height embankment.
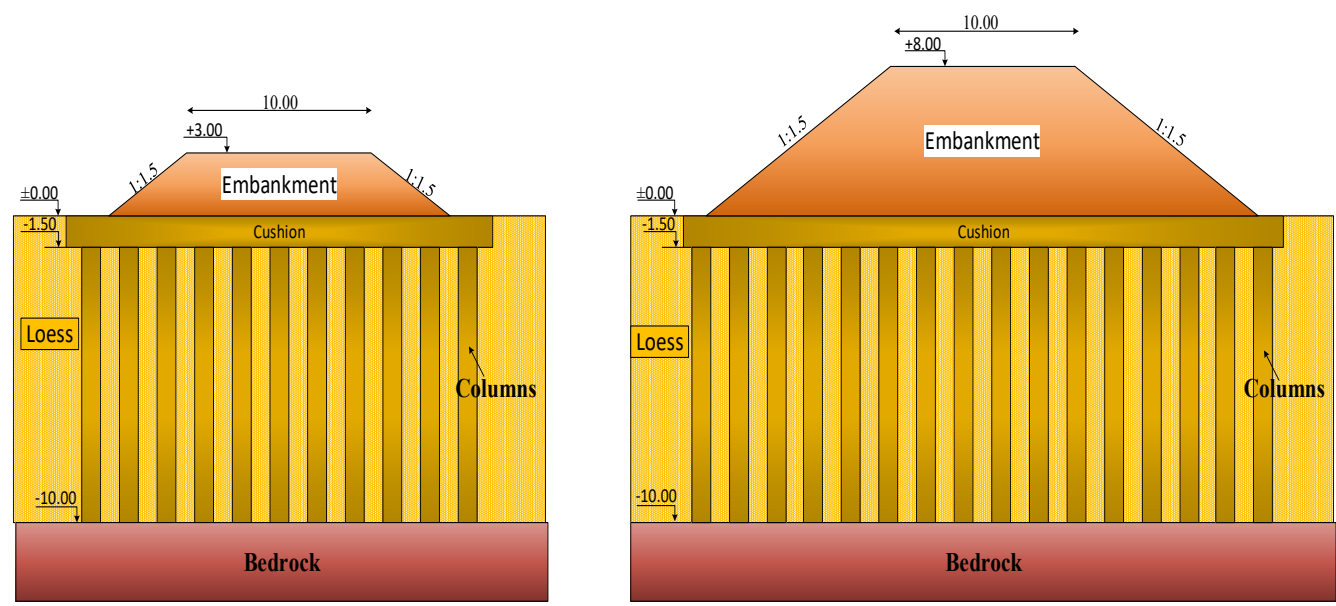

Figure 10. Calculation schemes

In both cases the next conditions were considered:

- The foundation soil consists in a $10 \mathrm{~m}$ layer of loess fallowed by bedrock;

- The thickness of the cushion is of $1.50 \mathrm{~m}$; 
ROMANIAN JOURNAL

OF TRANSPORT INFRASTRUCTURE

Cong Dinh Nguyen, Catalin Burlacu, Ioan Boti

Loessoid soils improvement - laboratory tests and road engineering applications

- The diameter of the colums is of $0.60 \mathrm{~m}$ with a distance between the columns of $1.80 \mathrm{~m}$;

- The top width of the embankment of 10m;

- The embankment slopes were considered 1:1.5.

In both cases, settlement calculations were made in different hypotheses, using the results from the laboratory tests as filling materials:

A. $3 \mathrm{~m}$ height embankment:

1. Loess + sand cushion;

2. Loess + sand cushion and columns;

B. $8 \mathrm{~m}$ height embankment:

1. Loess + cement cushion;

2. Loess + cement cushion and columns.

Also, all calculations have been made in the hypotheses when the layer of loess is wetted.

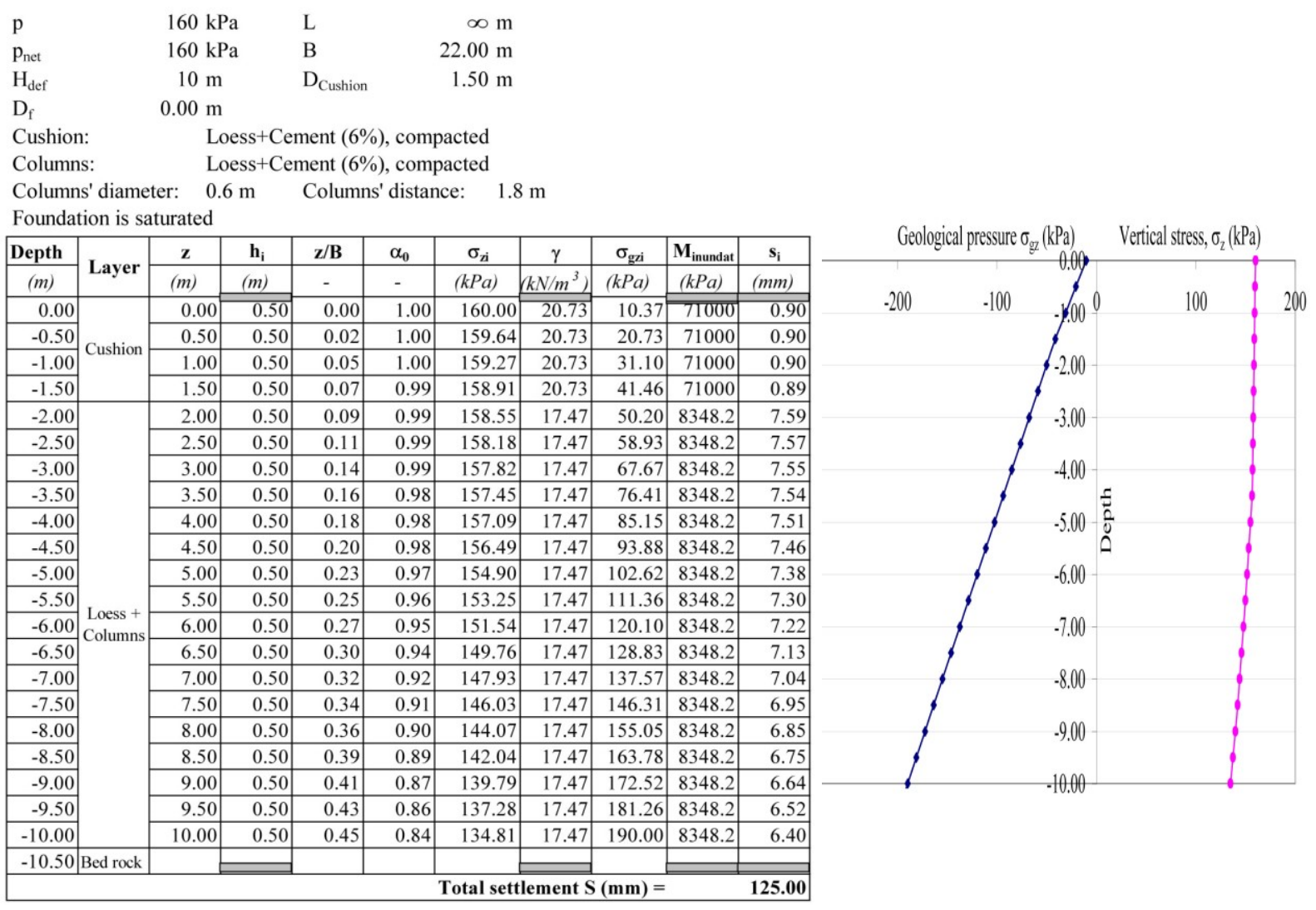

Figure 11. Settlement calculation example

All the results are presented in the table below. 
ROMANIAN JOURNAL

OF TRANSPORT INFRASTRUCTURE

Cong Dinh Nguyen, Catalin Burlacu, Ioan Boti

Loessoid soils improvement - laboratory tests and road engineering applications

Table 2 - Settlement calculation results

\begin{tabular}{|c|c|c|c|c|c|}
\hline & & & & Settlem & it $(\mathrm{mm})$ \\
\hline Case & Type & $\begin{array}{l}\text { Cushion } \\
\text { material }\end{array}$ & Columns material & Natural & Wetted \\
\hline & I $C$ ubion & Loess+Sand & & 73 & 829 \\
\hline & 1. Cusnion & Loess + Cement & & 69 & 820 \\
\hline A & & & Loess+Sand & 27 & 61 \\
\hline A & II.Cushion & Loess+Sand & Loess+Cement & 22 & 48 \\
\hline & Columns & I pess + Cement & Loess+Sand & 24 & 57 \\
\hline & & Loess+Cement & Loess + Cement & 19 & 43 \\
\hline & 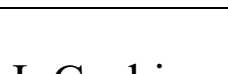 & Loess+Sand & & 190 & 1126 \\
\hline & 1. Cushion & Loess+Cement & & 181 & 1112 \\
\hline $\mathrm{R}$ & & I & Loess+Sand & 78 & 177 \\
\hline $\mathrm{D}$ & II.Cushion & Loess+Sand & Loess+Cement & 62 & 137 \\
\hline & $\stackrel{+}{\text { Columns }^{+}}$ & I ence+Cement & Loess+Sand & 69 & 164 \\
\hline & & Loess+Cement & Loess+Cement & 53 & 125 \\
\hline
\end{tabular}

\section{CONCLUSIONS}

Two laboratory programs were conducted, aiming to identify mixtures of loess and other materials (sand, bentonite, cement), in order to increase the mechanical characteristics and to reduce the wetting sensitivity of natural loess.

In both programs it was noticed that, after the loess was mixed with other materials, wetting sensitivity was significantly reduced and that, compared to the flooded natural loess, the values obtained for the mechanical characteristics were significantly better.

The results from the laboratory programs were used in some settlement calculations, in order to highlight the influence of using the studied mixtures as filling materials.

It can be observed that, for the loess in its natural state, the values of the settlements in all scenarios are not that high but, if wetted, the supplementary settlement has significant values.

So, in the first case of a $3 \mathrm{~m}$ height embankment, compacted cushions can be used, but only with a very strict limitation of wetting the loess layer (a 
drainage system should be used). If that's not possible, or if the impose settlements have small values, the columns solution should be used.

As the settlement results are similar with both mixtures, one can chose the filling material according to its stiffness. The loess-cement mixture acts like a weak concrete and, being brittle, it is not recommended to use it in cushions under a very deformable layer.

\section{REFERENCES}

[1]. R.J. BALLY, I. ANTONESCU: "Loessurile in constructii”. Tehnica Publishing House, Bucharest, Romania, 1971.

[2]. K., KIRSCH, W. SONDERMANN: “Geotechnical engineering handbook”. Volume 2: Procedures, Chapter 2.1. Ground improvement, 1 - 50. Ernst \& Sohn, Berlin, Germany, 2003.

[2]. A., STANCIU, I., LUNGU: “Fundatii”. Editura Tehnica, Bucuresti, Romania, 2006.

[3]. E. OLINIC: "Difficult foundation conditions in Romania", Proceeding of the $\mathbf{2 5}^{\text {th }}$ European Young Geotechnical Engineers Conference, Sibiu, Romania, 2016.

[4]. C., BURLACU, E., OLINIC, S., MANEA, P., UŢĂ: "Compacted soil columns for foundations on collapsible soils. Laboratory and in-situ experimental study". Proceedings of the 18th International Conference on Soil Mechanics and Geotechnical Engineering, Paris, France, 2013.

[5]. $\quad * * *$ NP 125 - "Normativ privind fundarea construcţiilor pe pământuri sensibile la umezire”. Bucharest, Romania, 2010.

[6]. *** AND 530 - "Instructiuni privind controlul calitatii terasamentelor rutiere". Bucharest, Romania, 2012. 